\title{
Prostanoid synthesis in the cerebral blood vessels of asphyxiated piglets
}

\author{
B. Kis ${ }^{1}, Z_{\text {Zsófia Mezei }}{ }^{1}$, P. Forgács ${ }^{2}$, Á. Gecse ${ }^{1}$, Gy. Telegdy ${ }^{1}$, F. Bari ${ }^{2}$ \\ Departments of ${ }^{1}$ Pathophysiology and ${ }^{2}$ Physiology, University of Szeged, \\ Faculty of Medicine, Szeged, Hungary \\ Received: May 22, 2001 \\ Accepted: October 30, 2001
}

\begin{abstract}
The aim of this study was to examine the effects of asphyxia-reventilation and hyperoxia on the cerebral blood perfusion and prostanoid production of the brain arteries and microvessels in piglets. After $10 \mathrm{~min}$ of asphyxia, animals were ventilated with room air, or with $100 \% \mathrm{O}_{2}$. Following 4 hours of recovery, the brains were perfused, cerebral arteries were removed and microvessels were isolated from the cortex. The microvessels and the arteries were incubated with $1-{ }^{14} \mathrm{C}$-arachidonic acid, and the $1-{ }^{14} \mathrm{C}$-prostanoids were then separated by means of overpressure thin-layer chromatography and were quantitatively determined. Under control conditions, the synthesis of dilatory prostanoids dominated the arachidonate cascade both in the microvessels and in the arteries. Asphyxia and reventilation with room air did not modify the prostanoid production. $\mathrm{O}_{2}$ ventilation greatly affected the prostanoid synthesis of the microvessels, with an enhancement of $\mathrm{PGD}_{2}$ up to $247 \pm 27 \%$. In the arteries, the production of $\mathrm{PGI}_{2}$ and of $\mathrm{PGE}_{2}$ was elevated to $272 \pm 15 \%$ and to $148 \pm 13 \%$, respectively. These findings indicate that $\mathrm{O}_{2}$ ventilation after asphyxia substantially increases the extent of prostanoid synthesis in the cerebral blood vessels.
\end{abstract}

Keywords: asphyxia, brain vessels, piglet, prostaglandin

Perinatal asphyxia, which occurs in approximately 6 per 1000 term live births, is the most important cause of neurologic injury in the newborn (31). The resuscitation of asphyxiated infants determines the functional and metabolic recovery of the nervous system and could be correlated with the delayed clinical outcome.

Correspondence should be addressed to

Ferenc Bari, PhD

University of Szeged

Faculty of Medicine

Department of Physiology

H-6720 Szeged, Dóm tér 10, Hungary

Fax: 36-62 545842

E-mail: BARI@phys.szote.u-szeged.hu 
Prostanoids produced from arachidonic acid (AA) are important autocrine/paracrine modulators of the cerebral circulation, especially in the newborn (8, 40). Dilator prostanoids contribute to the maintenance of the resting cerebral blood flow and to asphyxia-, hypercapnia- or hypotension-induced vasodilation (24). Prostanoids originating from cerebral microvessels also play a key role in the pathogenesis of fever (9) and in the cytokine-induced disruption of the blood-brain barrier (10).

Cyclooxygenase (COX) or prostaglandin H synthase (PGHS) is the enzyme that catalyzes the first two steps of the biosynthesis of prostaglandins (PGs) from AA. Two isoforms of PGHS, the "constitutive" COX-1 (25) and the "inducible" COX-2 (35), have recently been identified; they are very similar in structure and catalytic activity. COX-1 appears to be maximally expressed under stable physiological conditions and typically contributes to the intra- and intercellular communication by relatively quiescent cells (i.e. "housekeeping functions"). COX-2 is present only at very low levels in many quiescent cells, but it is readily induced by various agents, including growth factors, cytokines and endotoxins, and is therefore more involved in growth, cell differentiation and inflammation (38). However, COX-2 is constitutively expressed in specific cells in the central nervous system of the newborn $(12,28)$. COX-2 is the major functional contributor to the overall brain endothelial prostanoid synthesis in piglets (26).

Specific synthases release prostanoids $\left(\mathrm{PGD}_{2}, \mathrm{PGE}_{2}, \mathrm{PGF}_{2 \alpha}\right.$, prostacyclin and $\mathrm{TxA}_{2}$ ) from $\mathrm{PGH}_{2}$. In contrast with $\mathrm{COX}$, which is ubiquitously distributed in various tissues, different organs and tissues are supplied with a specific pattern of PG endoperoxide-metabolizing enzymes, which determine the relative amounts of the endproducts formed from AA.

It is known that the brain microvessels can produce $\mathrm{PGD}_{2}, \mathrm{PGE}_{2}, \mathrm{PGF}_{2 \alpha}$, prostacyclin and $\mathrm{TxA}_{2}$ via the COX pathway (14). As concerns the principal COX metabolites of the brain microvessels, there are controversial observations. Goehlert et al. (15) reported that prostacyclin was the major prostanoid formed in the rat cerebral microvessels, while others $(18,21)$ found $\mathrm{PGD}_{2}$ to be so. De Vries et al. (11) concluded that $\mathrm{PGE}_{2}$ was the main $\mathrm{COX}$ metabolite formed by cultured rat cerebral endothelial cells. The explanation of this controversy is not known at present.

Perinatal asphyxia and resuscitation are often followed by neurological sequelae. It has been shown that after anoxic stress and reoxygenization there is a selective impairment of cerebrovascular responsiveness, e.g. to dilator prostanoids (5). The mechanisms underlying the postasphyxial changes in cerebrovascular regulation are not known with certainty. Several data indicate that the impairment of the cerebrovascular responses is mainly dependent on the production and action of reactive oxygen species (2). In addition to prostanoid synthesis, COX can catalyze several oxidation reactions, causing cellular damage.

$\mathrm{O}_{2}$ administration is a common therapeutic tool in the treatment of hypoxic/asphyxiated newborns. Since many of the reactive species of $\mathrm{O}_{2}$ are generated during reperfusion, $\mathrm{O}_{2}$ ventilation could strongly affect the neurological outcome. 
Although postasphyxial increases in prostanoid levels in the cerebrospinal fluid have been reported (29), little is known about the eicosanoid production of cerebral vessels after hypoxic events $(13,21)$. Domoki et al. (13) reported rapid increases in COX-2 mRNA and protein levels in cerebral blood vessels following global ischemia. However, whether these changes are reflected in altered prostanoid production remains unexplored.

The purpose of the present study was to characterize the effects of asphyxia/ reventilation on prostanoid synthesis in cerebral microvessels and arteries. We tested the hypothesis that anoxic stress would stimulate eicosanoid production in a different manner at different points along the vascular tree. We compared the effects of ventilation with pure $\mathrm{O}_{2}$ and room air on the prostanoid production of the cerebral blood vessels.

\section{Materials and Methods}

\section{Materials}

The materials used in the experiments were of the following origins: arachidonic acid (grade I), $\mathrm{PGE}_{2}, \mathrm{PGD}_{2}, \mathrm{TxB}_{2}, \mathrm{PGF}_{2 \alpha}$, 6-keto-PGF $1 \alpha$, HHT and Medium 199 (Sigma, Hungary); 1- $\left({ }^{14} \mathrm{C}\right.$ )arachidonic acid (spec. act. $2035 \mathrm{Mbq} / \mathrm{mmol}$ ) (Amersham, $\mathrm{UK})$; silica gel thin-layer plates $(0.25 \mathrm{~mm})$ (Merck AG, Germany); sodium thiopental (Trapanal - Byk Gulden, Germany); a-chloralose (Fluka, Switzerland).

\section{Animals}

Newborn (1-2-day-old) domestic pigs of either sex, weighing between 1.2 and $1.6 \mathrm{~kg}$, were used. Animal experiments were performed with the approval of the Ethical Committee for the Protection of Animals in Research (University of Szeged, Hungary).

\section{Surgical preparation}

Anesthesia was induced with sodium thiopental $\left(30 \mathrm{~g} \mathrm{~kg}^{-1}\right.$, IP) followed by iv. injection of a-chloralose ( $\left.75 \mathrm{mg} \mathrm{kg}^{-1}\right)$. Supplemental doses of $\alpha$-chloralose were given as needed to maintain a stable level of anesthesia. Animals were intubated by tracheotomy and artificially ventilated with room air. The ventilation rate (approximately 20 breaths $\mathrm{min}^{-1}$ ) and tidal volume (approximately $20 \mathrm{ml} \mathrm{kg}^{-1}$ ) were adjusted to maintain the blood $\mathrm{pH}$ and gas values within the physiological ranges. In our study, the animals had baseline values within the normal ranges for arterial $\mathrm{pH}(7.35-7.45), \mathrm{pCO}_{2}$ (30-35 mm Hg) and $\mathrm{pO}_{2}(80-100 \mathrm{~mm} \mathrm{Hg})$. Body temperature was maintained at $37-38{ }^{\circ} \mathrm{C}$ by a water-circulating heating-pad. Systemic arterial blood pressure was recorded via a catheter placed into the right femoral artery and connected to a pressure transducer. The right femoral vein was catheterized for administration of drugs and fluids and for withdrawal of blood. The head of the piglet was fixed in a stereotaxic frame. 
Cortical blood perfusion was monitored by a laser Doppler flowmeter (Perimed PF4000, Sweden). The technique used to measure cortical blood flow by laser Doppler flowmetry (LDF) has been described previously (4). The flow probe was lowered via a burr hole with a micromanipulator without touching the brain surface.

\section{Statistics}

Data are expressed as mean + SE. Analysis of variance (ANOVA) followed by the Tukey B multiple comparison post hoc test was used to determine the significance of differences between the corresponding mean values. $\mathrm{p}<0.05$ was taken as statistically significant.

\section{Experimental protocol}

Anesthetized, instrumented piglets were divided into three groups: untreated controls $(n=6)$, asphyxia and reventilation with room air $(n=6)$, and asphyxia and reventilation with $100 \% \mathrm{O}_{2}(\mathrm{n}=6)$. Asphyxia was achieved by turning off the ventilator and clamping the endotracheal tube, as described previously (3). After $10 \mathrm{~min}$ of asphyxia, the tubing was unclamped and the animals were reventilated. Control animals were treated like the animals in the other two groups, but were not exposed to asphyxia. Following $4 \mathrm{~h}$ of recovery, the animals were killed with an IV injection of saturated $\mathrm{KCl}$, and the brains were perfused via the carotid arteries with cold, normal saline containing EDTA $\left(5.8 \mathrm{mmol}^{-1}\right)$ to remove blood from the brain vessels. Cerebral arteries were removed and microvessels were isolated from the parietal cortex.

\section{Isolation of cerebral microvessels}

Cerebral microvessels were isolated by the micromethod of Hwang et al. (17) with some modifications, as described previously (19). The cerebral cortex was freed from myelin and pial membranes. The cerebral cortex (300 mg wet weight) was homogenized in 10 volumes $\left(\mathrm{w} \mathrm{v}^{-1}\right)$ of standard isolation buffer $\left(0.32 \mathrm{~mol} \mathrm{l}^{-1}\right.$ sucrose, $3 \mathrm{mmol} \mathrm{l}^{-1}$ HEPES, $10 \mu \mathrm{mol} 1^{-1} \mathrm{CaCl}_{2} \cdot 2 \mathrm{H}_{2} \mathrm{O}$, pH 7.4), using 10 strokes in a Potter homogenizer with a teflon pestle at $100 \mathrm{rpm}$. The suspension was centrifuged for $10 \mathrm{~min}$ at $1000 \mathrm{~g}$. The pellet was homogenized in $3 \mathrm{ml}$ standard isolation buffer, and the centrifugation was repeated. The pellet was resuspended in $3 \mathrm{ml}$ standard isolation buffer and was centrifuged twice for $15 \mathrm{~s}$ at $100 \mathrm{~g}$. The supernatants (containing the microvessels) were collected, and were centrifuged at $200 \mathrm{~g}$ for $2 \mathrm{~min}$. The pellet was resuspended in $1.5 \mathrm{ml}$ standard isolation buffer, and was then centrifuged at $200 \mathrm{~g}$ for $1.5 \mathrm{~min}$. This was repeated twice. The pellet was resuspended in standard buffer and centrifuged for $5 \mathrm{~min}$ at $1000 \mathrm{~g}$. The pellet, containing mainly isolated brain capillaries, was suspended in $1 \mathrm{ml}$ Medium 199. The purity of the final preparation was verified by phase-contrast and light microscopy and by assaying the activity of gamma-glutamyl transpeptidase, the marker enzyme for microvessels, according to the method of Szász (36). The viability of the cells was tested by the trypan blue exclusion assay. 


\section{Analysis of eicosanoids}

Samples were preincubated at $37^{\circ} \mathrm{C}$ for $5 \mathrm{~min}$. The enzyme reaction was started by the introduction of tracer substrate, $1-\left({ }^{14} \mathrm{C}\right)-\mathrm{AA}(3.7 \mathrm{kBq}, 0.172 \mathrm{pmol})$, into the incubation mixture. Thirty minutes later, the enzyme reaction was stopped by bringing the $\mathrm{pH}$ of the incubation mixture to 3.0 with formic acid. According to our preliminary experiments, a period of $30 \mathrm{~min}$ was appropriate for in vitro labeling of the brain capillary endothelial cells. The samples were then extracted with ethyl acetate $(2 \times 3 \mathrm{ml})$, the prostanoids were separated by means of overpressure thin-layer chromatography and the amounts of the $\left({ }^{14} \mathrm{C}\right)$-prostanoids were determined quantitatively by liquid scintillation, as described previously (20). Instead of $\mathrm{TxA}_{2}$ and prostacyclin, we determined their stable metabolites $\left(\mathrm{TxB}_{2}\right.$ and 6-keto- $\left.\mathrm{PGF}_{1 \alpha}\right) . \mathrm{TxA}_{2}$ spontaneously hydrolyzes $\left(\mathrm{t}_{1 / 2}=30 \mathrm{~s}\right)$ to $\mathrm{TxB}_{2}(17)$, and prostacyclin spontaneously hydrolyzes $\left(\mathrm{t}_{1 / 2}=10 \mathrm{~min}\right)$ to 6 -keto-PGF $\mathrm{PG}_{1 \alpha}(37)$.

\section{Results}

Mean arterial blood pressure, heart rate, arterial blood gases and $\mathrm{pH}$ are listed in Tables I and II. The baseline values were within the normal ranges for anesthetized 1-2day-old piglets $(2,3,5)$. During asphyxia, there were significant decreases in arterial blood pressure and cortical blood flow, as illustrated in Figure 1. The blood gas values and $\mathrm{pH}$ had returned to normal by the end of the first hour after asphyxia (Tables I and II). In the $\mathrm{O}_{2}$ ventilated group, the $\mathrm{pO}_{2}$ was significantly elevated throughout the postasphyxia period.

Cortical blood perfusion was monitored during the experiment. We took a 10-min baseline period before asphyxia, and the average perfusion values were regarded as $100 \%$. As indicated in Tables I and II, there was a significant decrease in cortical perfusion in both asphyxiated groups. There was no significant difference between the room air-ventilated and $\mathrm{O}_{2}$-ventilated groups (Fig. 1).

In the cerebral microvessels, asphyxia followed by ventilation with room air caused only slight, not significant elevations in $\mathrm{PGD}_{2}, \mathrm{PGE}_{2}$, prostacyclin and $\mathrm{PGF}_{2} \alpha$ formation, while the synthesis of $\mathrm{TxA}_{2}$ decreased (Fig. 2). In the cerebral arteries, asphyxia + room air ventilation slightly attenuated the formation of $\mathrm{PGD}_{2}, \mathrm{PGE}_{2}$ and $\mathrm{PGF}_{2 \alpha}$, while the synthesis of prostacyclin was slightly increased (Fig. 3). The synthesis of TxA 2 did not change (Fig. 3). 


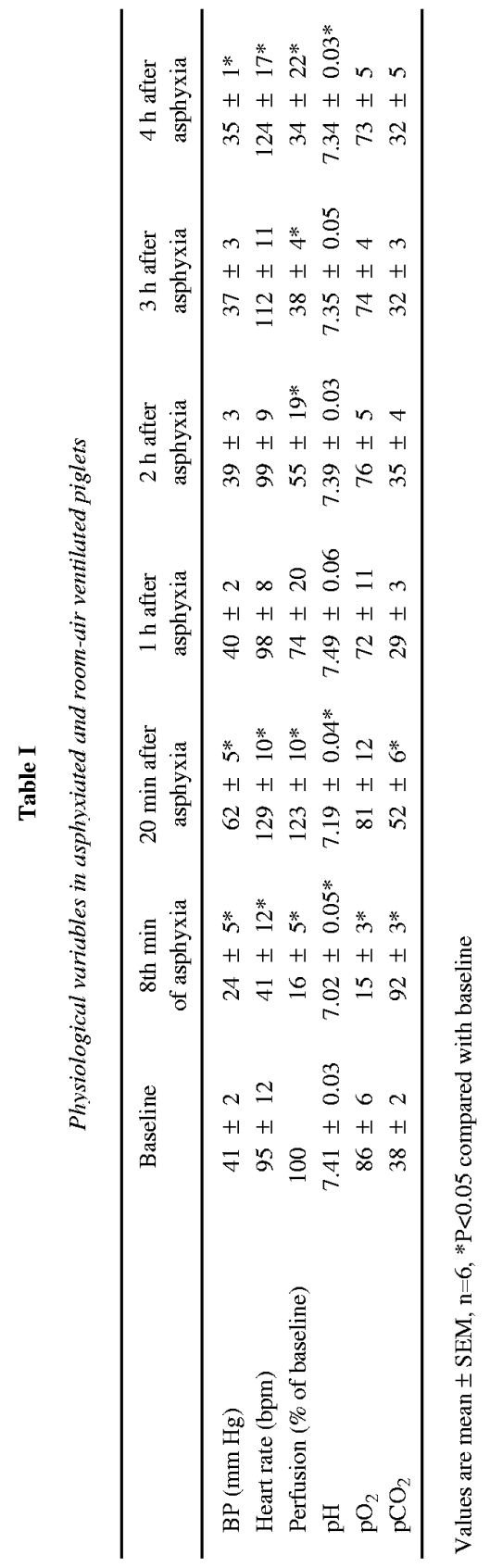




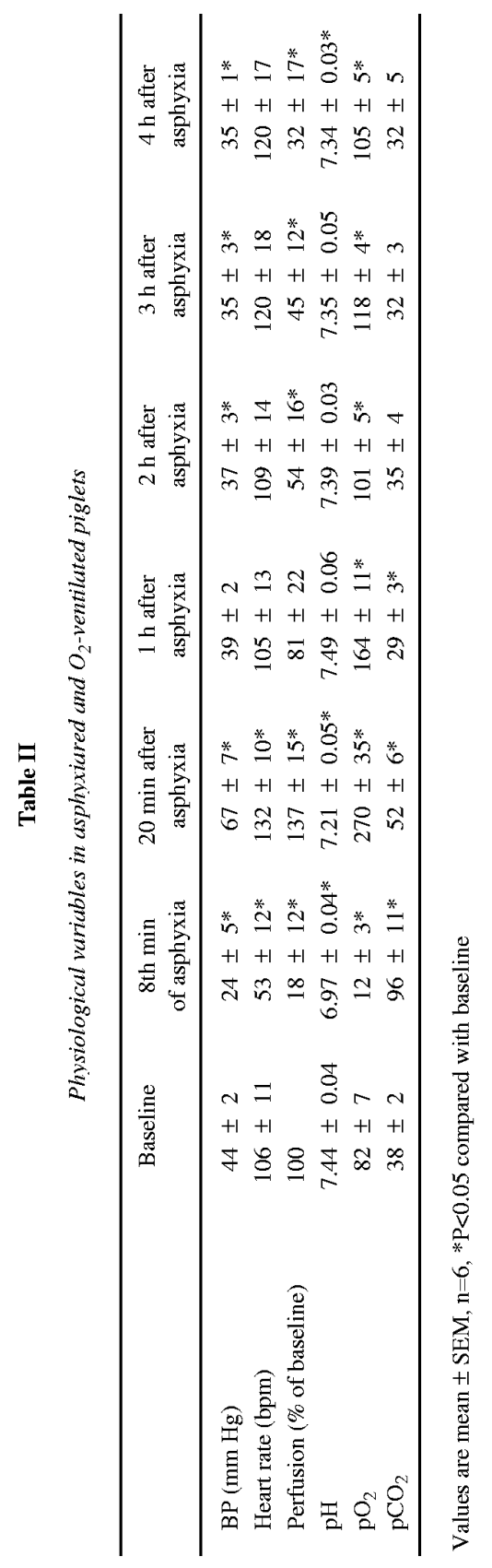




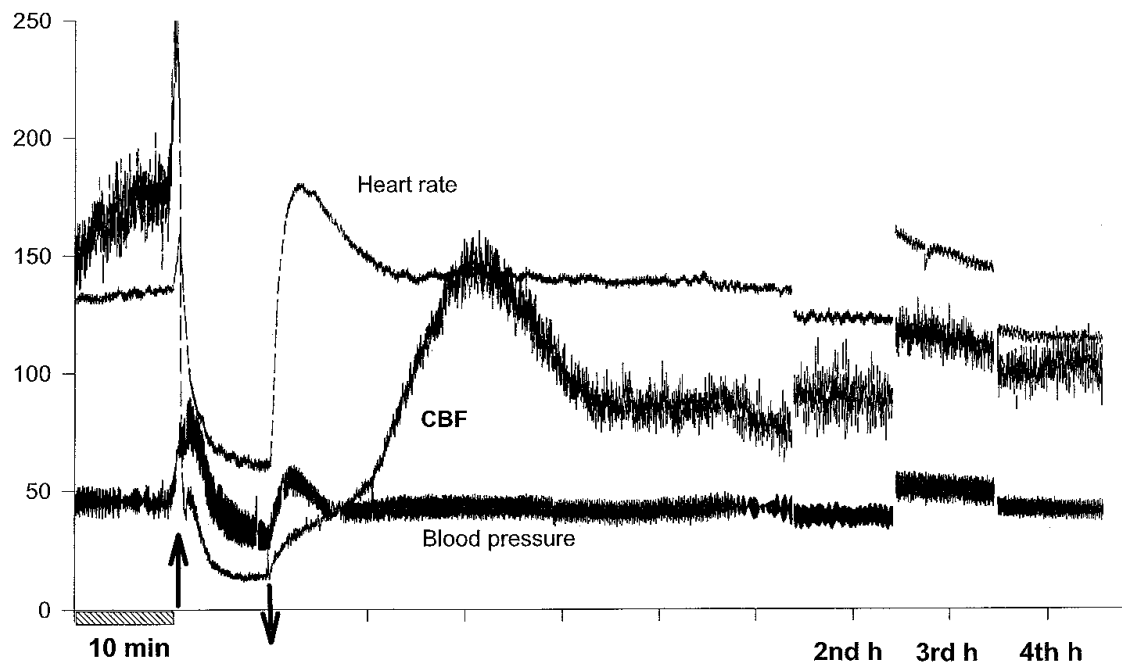

Fig. 1. Recording showing changes in cortical blood perfusion (CBF, using an arbitrary perfusion unit), mean arterial blood pressure $(\mathrm{mm} \mathrm{Hg})$ and heart rate (beats per minute) before, during and after $10 \mathrm{~min}$ of asphyxia. Arrows indicate the onset and end of asphyxia. In the 2nd, 3rd and 4th hours, the variables are shown by a representative 10 -min record.

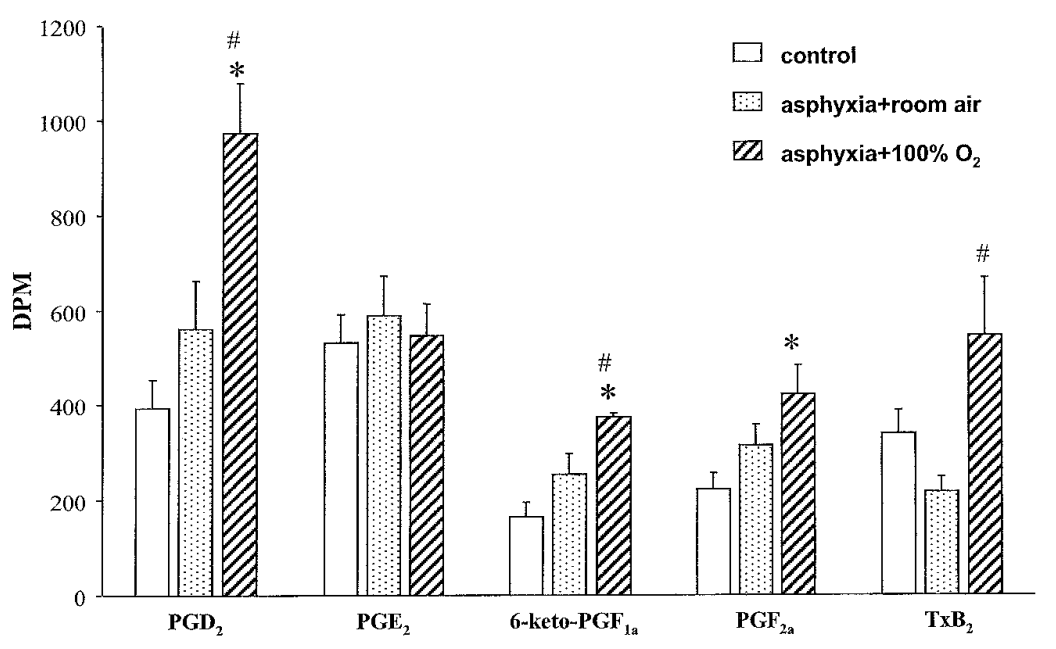

Fig. 2. Prostanoid synthesis of cerebral microvessels of asphyxiated piglets ventilated with either room air or $100 \% \mathrm{O}_{2}$. Bars represent the mean \pm S.E. in DPM/300 mg wet weight brain. Open bars, control group $(\mathrm{n}=8)$; dotted bars, room air-ventilated group $(n=7)$; hatched bars, $100 \% \mathrm{O}_{2}$-ventilated group $(\mathrm{n}=6)$. Significant differences are indicated by $*(\mathrm{p}<0.05)$ as compared to the control, and by $\#(\mathrm{p}<0.05)$ as compared to the room air-ventilated group 


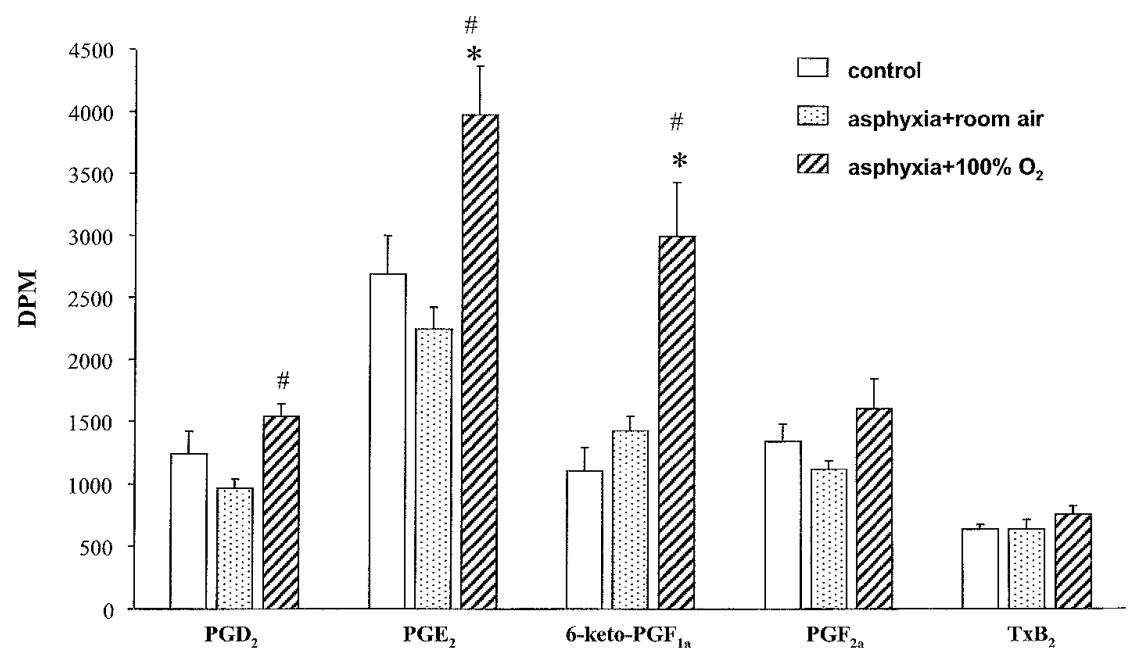

Fig. 3. Prostanoid synthesis of cerebral arteries of asphyxiated piglets ventilated with either room air or $100 \%$ $\mathrm{O}_{2}$. Bars represent the mean \pm S.E. in DPM/20 mg wet weight artery. Open bars, control group $(n=5)$; dotted bars, room air-ventilated group $(\mathrm{n}=6)$; hatched bars, $100 \% \mathrm{O}_{2}$-ventilated group $(\mathrm{n}=6)$. Significant differences are indicated by * $(\mathrm{p}<0.05)$ as compared to the control, and by \# $(\mathrm{p}<0.05)$ as compared to the room air-ventilated group

When the piglets were ventilated with pure $\mathrm{O}_{2}$ after the asphyxia, the syntheses of $\mathrm{PGD}_{2}$, prostacyclin, $\mathrm{PGF}_{2 \alpha}$ and $\mathrm{TxA}_{2}$ in the cerebral microvessels increased considerably, while the formation of $\mathrm{PGE}_{2}$ was not altered significantly (Fig. 2). In the cerebral arteries, $\mathrm{O}_{2}$ ventilation significantly elevated the syntheses of $\mathrm{PGD}_{2}, \mathrm{PGE}_{2}$ and prostacyclin as compared to the room air-ventilated group (Fig. 3). $\mathrm{O}_{2}$ ventilation did not influence the $\mathrm{PGF}_{2 \alpha}$ and $\mathrm{TxA}_{2}$ production of the cerebral arteries (Fig. 3).

\section{Discussion}

There are three major findings of this study. First, the prostanoid production of the cerebral arteries and microvessels is barely changed $4 \mathrm{~h}$ after asphyxia followed by room air ventilation. Second, ventilation with pure $\mathrm{O}_{2}$ after asphyxia significantly increased the extent of prostanoid synthesis in both the cerebral arteries and the microvessels. And third, $\mathrm{O}_{2}$ ventilation did not substantially improve the cortical perfusion following asphyxia.

Recent studies indicate that the AA metabolism plays a definite role in the mechanism of perinatal hypoxic brain injury. Studies of postischemic hemodynamic changes in the cerebral circulation have revealed that inhibition of the prostanoid 
synthesis preserves major vasodilator mechanisms (2). Several data indicate that impaired vasorelaxation is associated with the production and action of free radicals during the reperfusion period. Superoxide anion is produced in the cortex during asphyxia and reventilation in piglets (30). Although there are several sources for superoxide and other free radicals after anoxic stress, all of them require $\mathrm{O}_{2}$. An $\mathrm{O}_{2}$ load after asphyxia could enhance free radical production via either the mitochondrial or the arachidonate cascade. It seems that the COX pathway is the main source of superoxide in the brain of asphyxiated piglet (30) and also in the cerebral endothelial cells (22). The site of superoxide production is in the COX pathway when $\mathrm{PGG}_{2}$ is converted to $\mathrm{PGH}_{2}(6)$. The arachidonate cascade produces oxygen free radicals, and these can activate the cascade. Thus, superoxide production by this mechanism may result in a "vicious cycle" of accelerating radical production, which can lead to oxidant injury of the cells and tissues in pathologic conditions (6). It may be speculated that an enhanced production of superoxide anions or other $\mathrm{O}_{2}$-dependent substances might activate transcription factor NF- $\kappa \mathrm{B}$ and lead to an enhanced synthesis of COX-2 (34).

During asphyxia hypercapnia also develops which can influence prostanoid synthesis. Recently, Kövecs et al. (23) reported that hypercapnia stimulates PGE $_{2}$ but not $\mathrm{PGI}_{2}$ release in endothelial cells cultured from human fetal cerebral microvessels. Their finding is partly in conflict with our observations because we did not detect any significant change in prostanoid synthesis following asphyxia. On inhalation of room air both arterial blood and cerebral pH return quickly to baseline levels (1). Therefore in our study the hypercapnic exposure was much shorter than 60 min. However, we cannot completely rule out a stimulating effect of hypercapnia on prostanoid synthesis at longer exposure.

The data suggest that the rate-limiting factor for prostaglandin synthesis is the availability of free AA and/or the activity of COX. Recent findings have shown that COX-2 is the predominant isoform in piglet brain (12). Global cerebral ischemia resulted in elevation of the COX-2, but not the COX-1 protein levels by $4-6 \mathrm{~h}$. The same tendency was observed for both protein and mRNAs. In contrast with global cerebral ischemia, the COX-2 mRNA and protein levels did not increase after asphyxia (12). Domoki et al. (13) recently extended the observations to the cerebral arteries. In consequence of the methods used for the determination of the COX-2 protein levels, neither Dégi et al. (12) nor Domoki et al. (13) were able to investigate the microvessels of the brain separately. The question of whether minor changes occur in the prostanoid synthesis in the cerebral microvessels and arteries after asphyxia therefore remained to be answered. Our method involving the use of isolated cerebral microvessels and arteries confirmed and extended the findings of Dégi et al. (12). It revealed that, $4 \mathrm{~h}$ after asphyxia, there is only minimal if any increase at all in the potential for eicosanoid synthesis in the brain microvessels and arteries. Since COX-2 induction in response to hypoxia in endothelial cells is dependent upon activation of the transcription factor NF$\kappa \mathrm{B}$ (34), we speculate that respiratory acidosis or some other attribute of asphyxia (e.g. an elevated adenosine level (27)) leads to suppression of this transcription factor. 
There are several consequences of $\mathrm{O}_{2}$ ventilation after asphyxia. First of all, it did not improve the cortical perfusion after the hypoxic insult, as indicated by LDF. Although there was no marked increase in intracranial pressure (unpublished observations), this could be in association with moderate tissue edema. LDF allowed sensitive, stable and reproducible estimates of the microcirculation with high temporal resolution. The experimental design may complicate the interpretation of the LDF data. One concern might be that we did not change the position of the probe during the 4-5-h observation period. Since LDF monitors only a small area within the cortex, slight changes in brain volume following asphyxia would bias perfusion values. No macroscopic intracortical hemorrhage due to placement of the tip was observed, but the brain tissue surrounding the probe was not subjected to microscopic examination in this study.

There was a marked increase in prostanoid synthetic capacity in both the large and the microvessels. In the cerebral arteries, the most profound increases were in the extents of $\mathrm{PGE}_{2}$ and $\mathrm{PGI}_{2}$ synthetis. The effect of hyperoxia alone on formation of prostanoids in brain vessels in vivo is unknown. Indirect data suggest that it might not have any significant role in changing the composition AA products. Prostaglandin release from microvessels isolated from the rabbit cerebral cortex did not show significant differences when incubated either with room air or $100 \% \mathrm{O}_{2}(32)$. Hyperoxia did not affect vascular formation of prostanoids induced by vasoactive agents (7). Similarly, 45-min oxygen ventilation did not modify the choroidal hemodynamic responses to hyperoxia (16). Our findings challenge the hypothesis that post-asphyxic oxygen-ventilation is necessary to modify of the prostanoid synthetic capability of brain microvessels in the first hours following reperfusion.

The shift toward dilator prostanoids could explain our observation that in asphyxiated piglets there was a slight increase in pial arteriolar diameters. Opposing the dilator effect, the overproduction of oxygen radicals and the formation of ONOO- from nitric oxide could inactivate $\mathrm{PGI}_{2}$-induced vasodilation, as suggested by Zou et al. (39).

In the microvessels, the dominance of dilator components was not obvious. Elevation of $\mathrm{TxA}_{2}$ synthesis could enhance the endothelium-dependent vasoconstriction. Although there is some debate as to whether prostanoids of capillary origin contribute to regulation of the microvessel tone, an increased activity of COX can lead to an enhanced free radical production in the microcirculatory network, and an elevated free radical production can intensify the neurological damage. Our results highlight the importance of the well-controlled administration of $\mathrm{O}_{2}$ to the newborn after asphyxia. Augmented levels of COX, with resultant increases in the production of prostaglandins and superoxide anion, may lead to disrupted cellular relationships, the abnormal functioning of neural tissues, inappropriate blood flow responses, and/or enhanced cell damage following additional pathological conditions. For example, enhanced levels of COX could disrupt the balance between the dilator nitric oxide and the constrictor PGs and TxA 2 in maintaining an appropriate cerebral blood flow. 
In conclusion, $\mathrm{O}_{2}$ ventilation after asphyxia substantially increases the extent of prostanoid synthesis in the cerebral blood vessels. The change in prostanoid synthetic capacity may reflect elevated and biologically active COX levels. The altered balance between the dilator and constrictor prostanoids may affect the cerebral blood perfusion and the process of development of brain injury.

\section{Acknowledgements}

Supported by OTKA (T-026295 and T-25628) and by the Hungarian Ministry of Welfare (T-07614/97 and T-04135/97).

\section{REFERENCES}

1. Andrews RJ, Bringas JR, Alonzo G: Cerebrospinal fluid $\mathrm{pH}$ and $\mathrm{PCO} 2$ rapidly follow arterial blood $\mathrm{pH}$ and PCO2 with changes in ventilation. Neurosurgery. 34, 466-470 (1994)

2. Bari F, Errico RA, Louis TM, Busija D: Differential effects of short-term hypoxia and hypercapnia on N-methyl-D-aspartate-induced cerebral vasodilatation in piglets. Stroke. 27, 1634-1639 (1996)

3. Bari F, Errico RA, Louis TM, Busija DW: Influence of hypoxia/ischemia on cerebrovascular responses to oxytocin in piglets. J. Vasc. Res. 34, 312-320 (1997)

4. Bari F, Horváth Gy, Benedek Gy: Dexmedetomidine induced decrease in cerebral blood flow is attenuated by verapamil in rats: a laser Doppler study. Can. J. Anaesth. 40, 748-754 (1993)

5. Bari F, Louis TM, Meng W, Busija DW: Global ischemia impairs ATP-sensitive $\mathrm{K}^{+}$channel function in cerebral arterioles in piglets. Stroke. 27, 1874-1881 (1996)

6. Betz AL (1993): Oxygen free radicals and the brain microvasculature. In: The Blood-Brain Barrier, ed Pardridge WM., Raven Press, New York, pp. 303-321.

7. Bjoro K, Haugen G, Stray-Pedersen S: Altered prostanoid formation in human umbilical vasculature in response to variations in oxygen tension. Prostaglandins. 34, 377-384 (1987)

8. Busija DW (1997): Eicosanoids and Cerebrovascular Control. In: Primer on Cerebrovascular Diseases, eds Welch KMA, Caplan LR, Reis DJ, Siesjö Bo K, Weir B, Academic Press, New York, pp. 93-96

9. Cao C, Matsumura K, Yamagata K, Watanabe Y: Endothelial cells of the rat brain vasculature express cyclooxygenase-2 mRNA in response to systemic interleukin-1alfa: a possible site of prostaglandin synthesis responsible for fever. Brain Res. 733, 263-272 (1996)

10. de Vries HE, Blom-Roosemalen MCM, van Oosten M, de Boer AG, van Berkel TJC, Breimer DD, Kuiper $\mathrm{J}$ : The influence of cytokines on the integrity of the blood-brain barrier in vitro. $\mathrm{J}$. Neuroimmunol. 64, 37-43 (1996)

11. de Vries HE, Hoogendoorn KH, van Dijk J, Zijlstra FJ, van Dam A, Breimer DD, van Berkel TJC, de Boer AG, Kuiper J: Eicosanoid production by rat cerebral endothelial cells: stimulation by lipopolysaccharide, interleukin-1 and interleukin-6. J. Neuroimmunol. 59, 1-8 (1995)

12. Dégi R, Bari F, Thrikawala N, Beasley TC, Thore C, Louis TM, Busija DW: Effects of anoxic stress on prostaglandin H synthase isoforms in piglet brain. Dev. Brain. Res. 107, 265-276 (1998)

13. Domoki F, Veltkamp R, Thrikawala N, Robins G, Bari F, Louis TM, Busija DW: Ischemia/reperfusion rapidly increases cyclooxigenase (COX)-2 expression in piglet cerebral arteries. Am. J. Physiol. 277, H1207-1214 (1999) 
14. Gecse Á, Ottlecz A, Mezei Zs, Telegdy Gy, Joó F, Dux E, Karnushina I: Prostacyclin and prostaglandin synthesis in isolated brain capillaries. Prostaglandins. 23, 287-297 (1982)

15. Goehlert UG, Ng Ying Kin, NMK, Wolfe LS: Biosynthesis of prostacyclin in rat cerebral microvessels and the choroid plexus. J. Neurochem. 36, 1192-1201 (1981)

16. Hardy P, Peri KG, Lahaie I, Varma DR, Chemtob S: Increased nitric oxide synthesis and action preclude choroidal vasoconstriction to hyperoxia in newborn pigs. Circ. Res. 79, 504-511 (1996)

17. Hwang SM, Weiss S, Segal S: Uptake of L-(35S)Cystine by isolated rat brain capillaries. J. Neurochem. 35, 417-424 (1980)

18. Joó F, Dux E, Karnushina IL, Halász N, Gecse Á, Ottlecz A, Mezei Zs: Histamine in brain capillaries. Agents and Actions. 11, 129-134 (1981)

19. Kis B, Gaspar T, Mezei Zs, Gecse Á, Telegdy Gy: Pituitary adenylate cyclase-activating polypeptide inhibits the cyclooxygenase pathway of rat cerebral microvessels. Acta. Physiol. Scand. 167, 43-47 (1999)

20. Kis B, Szabo CA, Pataricza J, Krizbai IA, Mezei Zs, Gecse Á, Telegdy Gy, Papp JG, Deli MA: Vasoactive substances produced by cultured rat brain endothelial cells. Eur. J. Pharm. 368, 35-42 (1999)

21. Koide T, Gotoh O, Asano T, Takakura K: Alterations of the eicosanoid synthetic capacity of rat brain microvessels following ischemia: Relevance to ischemic brain edema. J. Neurochem. 44, 85-93 (1985)

22. Kontos HA, Wei EP, Ellis EF, Jenkins LW, Povlishock JT, Rowe GT, Hess ML: Appearance of superoxide anion radical in cerebral extracellular space during increased prostaglandin synthesis in cats. Circ. Res. 57, 142-151 (1985)

23. Kövecs K, Komjáti K, Marton T, Skopál J, Sándor P, Nagy Z: Hypercapnia stimulates prostaglandin $\mathrm{E}_{2}$ but not prostaglandin $\mathrm{I}_{2}$ release in endothelial cells cultured from microvessels of human fetal brain. Brain Res. Bull. 54, 387-390 (2001)

24. Leffler CW: Prostanoids: Intrinsic modulators of cerebral circulation. News Physiol. Sci. 12, 72-77 (1997)

25. Miyamoto T, Ogino N, Yamamoto S, Hayaishi O: Purification of prostaglandin endoperoxide synthase from bovine vesicular gland microsomes. J. Biol. Chem. 251, 2629-2636 (1976)

26. Parfenova H, Eidson TH, Leffler CW: Upregulation of COX-2 in cerebral microvascular endothelial cells by smooth muscle cell signals. Am. J. Physiol. 273, C277-C288 (1997)

27. Park TS, Van Wylen DG, Rubio R, Berne RM: Brain interstitial adenosine and sagittal sinus blood flow during systemic hypotension in piglet. J. Cereb. Blood. Flow Metab. 8, 822-828 (1988)

28. Peri KG, Hardy P, Li DY, Varma DR, Chemtob S: Prostaglandin G/H synthase is a major contributor of brain prostaglandins in the newborn. J. Biol. Chem. 270, 24615-24620 (1995)

29. Pourcyrous M, Leffler C, Busija D: Postasphyxial increases in prostanoids in cerebrospinal fluid of piglets. Pediatr. Res. 24, 229-232 (1988)

30. Pourcyrous M, Leffler CW, Bada HS, Korones SB, Busija DW: Brain superoxide anion generation in asphyxiated piglets and the effect of indomethacin at therapeutic dose. Pediatr. Res. 34, 366-369 (1993)

31. Robertson NJ, Edwards AD: Recent advances in developing neuroprotective strategies for perinatal asphyxia. Curr. Opin. Pediatr. 10, 575-580 (1998)

32. Rodrigues AM, Gerritsen ME: Prostaglandin release from isolated rabbit cerebral cortex micro-vesselscomparison of 6-keto PGF1 alpha and PGE2 release from micro-vessels incubated in $100 \% \mathrm{O}_{2}$, room air and $95 \% \mathrm{~N} 2: 5 \% \mathrm{CO}_{2}$. Stroke $15,717-722$ (1984)

33. Samuelsson B, Goldyne M, Granstrom E, Hamberg M, Hammarstrom S, Malmsten C: Prostaglandins and thromboxanes. Ann. Rev. Biochem. 47, $997-1029$ (1978) 
34. Schmedtje JF, Jr Ji YS, Liu WL, DuBois RN, Runge MS: Hypoxia induces cyclooxygenase-2 via the NF-kappaB p65 transcription factor in human vascular endothelial cells. J. Biol. Chem. 272, 601-608 (1997)

35. Simmons DL, Levy DB, Yannoni Y, Erikson RL: Identification of a phorbol ester-repressible v-srcinducible gene. Proc. Natl. Acad. Sci. USA. 86, 1178-1182 (1989)

36. Szász G: New substrates for measuring gamma-glutamyl transpeptidase activity. Z. Klin. Chem. Klin. Biochem. 12, 228 (1974)

37. Whittaker N, Bunting S, Salmon J, Moncada S, Vane JR, Johnson RA, Morton DR, Kinner JH, Gorman RR, McGuire JC, Sun FF: The chemical structure of prostaglandin X (prostacyclin). Prostaglandins. 12, 915-928 (1976)

38. Williams CS, Dubois RN: Prostaglandin endoperoxide synthase: Why two isoforms? Am. J. Physiol. 270, G393-G400 (1996)

39. Zou M, Jendral M, Ullrich V: Prostaglandin endoperoxide-dependent vasospasm in bovine coronary arteries after nitration of prostacyclin synthase. Br. J. Pharmacol. 1283-1292 (1999)

40. Zuckerman SL, Armstead WM, Hsu P, Shibata M, Leffler CW: Age dependence of cerebrovascular response mechanisms in the domestic pig. Am. J. Physiol. 271, H535-H540 (1996) 